\begin{aligned} & $\begin{array}{c}\text { Науковий вісник Нлту України } \\ \text { Scientific Bulletin of UNFU } \\ \text { https://nv.nltu.edu.ua }\end{array}$ (c) (i) ISSN 1994-7836 (print) \\ & ISSN 2519-2477 (online) \\ & $\begin{array}{l}\text { https://doi.org/10.36930/40310504 } \\ \text { Article received } 12.10 .2021 \mathrm{p} .\end{array} \\ & \begin{array}{l}\text { Article accepted 25.11.2021 p. } \\ \text { UDC 581.5:582.6(504.305.4) }\end{array} \begin{array}{r}\text { O. M. Leshcheniuk } \\ \text { afedorova550@gmail.com }\end{array} \\ &$\hline\end{aligned}

О. М. Лещенюк, М. Ю. Мазура

Інститут еволючійної екології, НАН України, м. Київ, Україна

\title{
ЗМІНА АНАТОМІЧНИХ ПОКАЗНИКІВ ЛИСТКІВ FORSYTHIA EUROPAEA DEGEN \& BALD. ЗА ДIÏ ВИКИДІВ АВТОТРАНСПОРТУ
}

На сьогодні під час високої автомобілізації актуальним є дослідження впливу інгредієнтів автотранспортних викидів на зелені насадження в мегаполісах, які підтримують екологічну рівновагу в урбоекосистемі та слугують індикаторами забруднення довкілля. Forsythia europaea Degen \& Bald. поширена у фітодизайні Києва у різноманітних місцях, де піддається постійному антропогенному пресу. Тому доцільним $\epsilon$ анатомо-морфологічне дослідження структури листків $F$. еuropaеa для визначення стійкості виду в умовах Київського мегаполісу та моніторингу забруднення довкілля. Матеріалом дослідження слугували рослини $F$. europaea, відібрані з п'яти моніторингових ділянок Києва, які різнилися інтенсивністю транспортних потоків та віддаленістю від автострад: слабко забруднені (середня часова інтенсивність руху автотранспорту менш ніж 1000 авто/год, точка 1 та 3 - вулиці Ф. Максименка та Жмеринська) та дуже сильно забруднені (інтенсивність руху перевищує 4000 авто/год, точка 2 - проспект Перемоги, точка 4 - вул. Генерала Жмаченка, точка 5 - Одеська площа). Встановлено особливості анатомо-морфологічної будови листків $F$. еигораеа за різних умов зростання. Виявлено, що листки гіпостоматичні, покриті кутикулою з обох сторін, адаксіальний та абаксіальний епідерміси утворені одним шаром клітин, мезофіл дорзовентральний, багатошаровий. З'ясовано, що у варіантах, де рослини зазнавали інтенсивнішого впливу інгредієнтів автотранспортних викидів, відбувалися зміни показників гістологічної структури листка у бік ксероморфності, а саме: потовщувалася кутикула, зменшувалися розміри продихів, ступінь їх відкритості, збільшувалася щільність клітин абаксіального епідермісу та продихів, зростали показники продихового індексу та індексу ксероморфності, з'являлися поодинокі продихи на адаксіальній поверхні листків. Такі зміни показників анатомічної структури листкової пластинки $F$. europaеa можна розглядати як адаптивну реакцію рослин до зростання в антропогенно трансформованому середовищі, що свідчить про пластичність виду та достатній рівень життєвості в умовах забруднення. Вважаємо, що параметри гістологічної структури листка F. europaea можна використовувати як тест-показники для індикації аерогенного забруднення довкілля.

Ключові слова: забруднення; Forsythia; анатомія листка; пластичність; ксероморфітизація.

\section{Вступ / Introduction}

На сьогодні забруднення повітря є серйозною проблемою великих густонаселених промислових міст світу та України, зокрема і Києва. Основним джерелом забруднення Київського мегаполісу є автотранспорт, частка шкідливих речовин від якого становить $85-90 \%$, а його негативний вплив щорічно зростає, що пов'язано 3 високими темпами автомобілізації [6]. За даними AUTO-Consulting, на початок 2021 р. показник автомобілізації у Києві вперше становив 407 авто на 1000 жителів, а кількість автомобілів за рік збільшилася на 4,1% (50 тис. автомобілів) [7]. Таке перевантаження автошляхів транспортом спричинює у місті часті затори, що призводить до перевищення гранично допустимих концентрацій шкідливих речовин (ГДК) та негативно впливає на здоров'я людей (спричиняють до $70 \%$ усіх хвороб у містах) та міську біоту. За найбільшою масовою часткою у відпрацьованих газах автомобілів присутні оксид вуглецю, двоокис азоту, вуглеводні, двоокис сірки, пил, бензопірен, свинець [3].

Зелені насадження за таких умов виконують низку важливих функцій: природного фільтра на шляху полютантів (затримують від 21 до $86 \%$ пилу, а частину викидів поглинають), створюють сприятливий мікроклімат (знижують температуру повітря, підвищують вологість), зменшують шум, формують комфортне середовище для населення, збагачують архітектурно-планувальні композиції міського простору, підтримують екологічну рівновагу в урбоекосистемі $[18,20,23]$. Також вони $є$ надійними індикаторами забруднення довкілля, оскільки змушені адаптуватися до стресу за допомогою фізіолого-біохімічних та анатомо-морфологічних перебудов організму $[4,11,20]$. Ступінь адаптованості рослин залежить від виду рослин, комплексу екологічних умов зростання та характеру реакції рослин на дію забруднювачів довкілля різного походження - одні види рослин в умовах урбанізації сильно пошкоджуються, стають пригніченими, а інші добре пристосовуються $[2$, $8,10,20]$. Вітчизняні та закордонні науковці часто зас-

Інформація про авторів:

Лещенюк Олена Миколаївна, пров. інженер, відділ фітоекології рослин. Email: afedorova550@gmail.com; https://orcid.org/0000-0003-0597-7251

Мазура Марина Юріївна, канд. біол. наук, наук. співробітник, відділ дендрології та паркознавства. Email: marinamazura1978@gmail.com; https://orcid.org/0000-0001-5260-1893

Цитування за ДСТУ: Лещенюк О. М., Мазура М. Ю. Зміна анатомічних показників листків Forsythia Europaea Degen \& Bald. за дії викидів автотранспорту. Науковий вісник НЛтУ України. 2021, т. 31, № 5. С. 29-35.

Citation APA: Leshcheniuk, O. M., \& Mazura, M. Yu. (2021). Changes in the anatomical parameters of the leaves of Forsythia Europaea Degen \& Bald. caused by motor vehicle emissions. Scientific Bulletin of UNFU, 31(5), 29-35. https://doi.org/10.36930/40310504 
тосовують різноманітні показники деревних та трав'яних рослин у визначенні рівня антропогенного тиску: життєвий стан насаджень, зміну морфології листків та його пошкодження, чутливість пилку, нагромадження тяжких металів, сезонний ритм розвитку тощо $[4,13,17$, 19]. Особливо цікавими є роботи з дослідження анатомічної структури асиміляційних органів рослин, оскільки вона відображає реакцію рослин на умови навколишнього середовища, в якому вони ростуть $[2,5,21,26]$.

Представники роду Forsythia Vahl. характеризуються високими декоративними якостями під час яскравого раннього цвітіння навесні та гарного забарвлення листя восени, тому їх часто використовують в озелененні міського середовища в різних стилях та елементах ландшафтного дизайну. В Україні інтродуковано 6 видів форзиції [9]. Найвищу декоративність серед них мають рослини Forsythia europaea Degen \& Bald. [16]. У Києві iii вирощують у різноманітних місцях (ботанічних садах, парках, скверах, прибудинкових територіях, вздовж вулиць), де піддається постійному антропогенному пресу. 3 огляду на це доцільним є анатомо-морфологічне дослідження структури листків $F$. europaea для визначення стійкості виду в умовах Київського мегаполісу та моніторингу забруднення довкілля.

Об'єкт дослідження - рослини $F$. еитораеа, які зростали у культурфітоценозах Києва з різним ступенем антропогенного навантаження.

Предмет дослідження - методи і засоби визначення анатомо-морфологічної структури листкових пластинок виду $F$. еuropaea.

Мета роботи - дослідити вплив аерогенного забруднення різної інтенсивності на показники анатомо-морфологічної структури листків $F$. europaea, визначити стійкість виду в міському середовищі та з'ясувати можливість використання гістологічних параметрів листка $F$. europaea як індикаторів забруднення довкілля.

Для досягнення зазначеної мети визначено такі ocновні завдання дослідження: проаналізувати особливості анатомо-морфологічної будови листкової пластинки $F$. europaea з різних місць зростання; з'ясувати специфіку реакції рослин на вплив забруднення.

Наукова новизна отриманих результатів дослідження - вперше описано анатомо-морфологічну структуру листків $F$. europaеa в урбанізованих умовах, з'ясовано специфіку пристосувань рослин до впливу аерополютантів.

Практична значущість результатів дослідження доцільно застосувати для визначення стійкості виду в умовах мегаполісу та моніторингу стану довкілля.

Аналіз останніх досліджень та публікацій. За даними вітчизняних наукових публікацій за останні роки було досліджено сезонний ритм розвитку, морфологічні, еколого-біологічні особливості деяких видів та сортів роду Forsythia Vahl з перспективою гібридизації та подальшого залучення високо декоративних культиварів у ландшафтний дизайн $[9,16]$. У дослідженнях закордонних науковців висвітлено лікарські властивості видів Forsythia, застосування їх у медицині під час лікування різних захворювань, зокрема і COVID-19, що зумовлено вмістом значної кількості різноманітних біологічно активних речовин $[15,25]$. Частково описано епідермальну мікроструктуру листків триби Forsythieae [10]. Дослідження анатомічної структури $F$. europaea в урботехногенних умовах раніше не проводили, тому є актуальним на сьогодні.

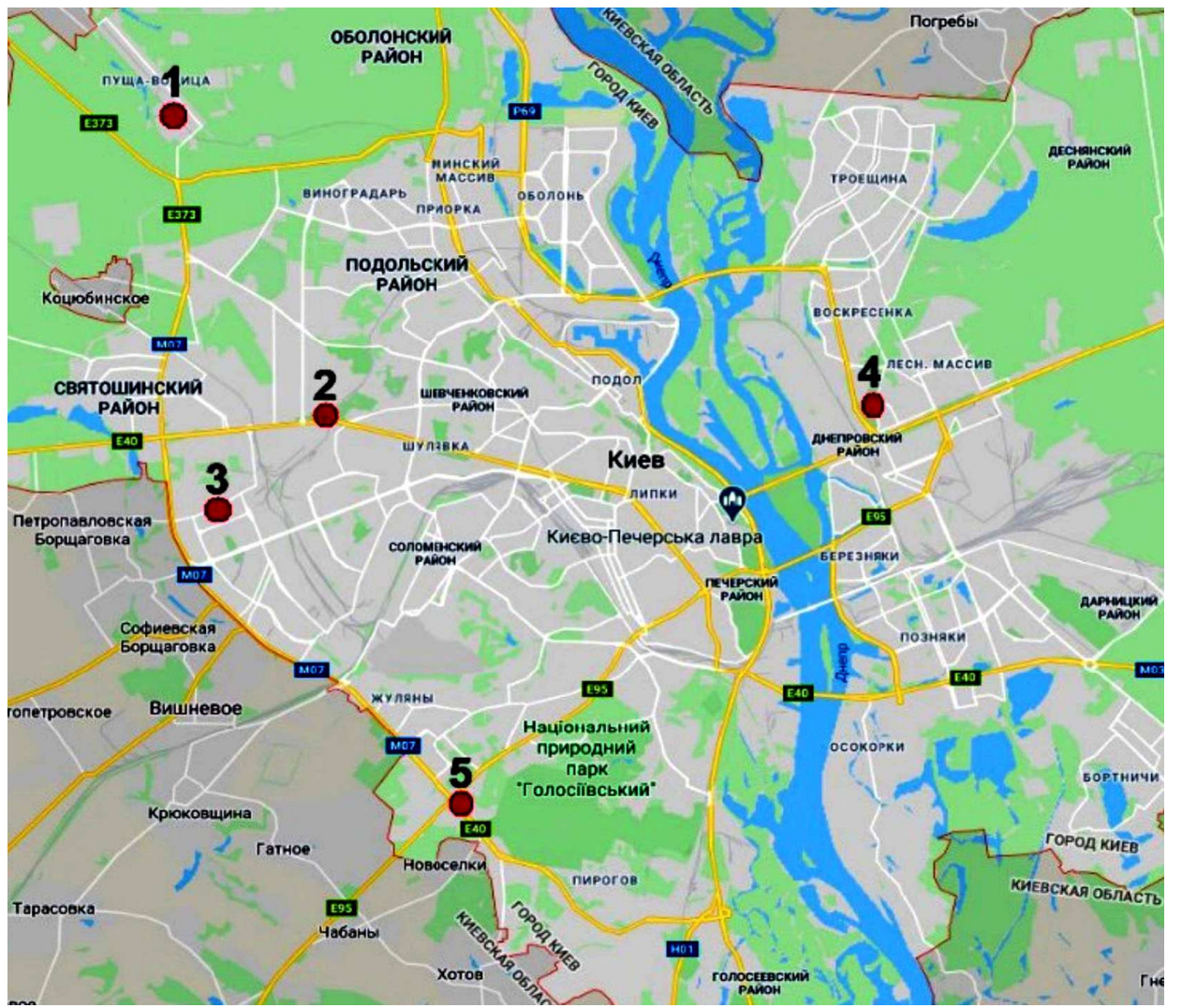

Рис. 1. Картосхема розташування моніторингових ділянок у м. Київ / Map of the location of monitoring sites in Kyiv: 1 - вул. Ф. Максименка (парк "Пуща Водиця") / F. Maksymenko Street (Pushcha Voditsa Park); 2 - проспект Перемоги (ст. м. "Нивки") / Victory Avenue (Nyvky metro station); 3 - вул. Жмеринська (парк "Совки") / Zhmerynska Street (Sovky Park); 4 - вулиця Генерала Жмаченка (парк "Перемога") / General Zhmachenko Street (Victory Park); 5 - Одеська площа / Odessa Square 
Матеріали та методи дослідження. Матеріал дослідження - листки виду $F$. europaea, відібрані в культурфітоценозах Києва. Для встановлення рівня впливу полютантів на структуру листкової пластинки $F$. europaea обрано 5 моніторингових точок відбору матеріалу 3 різною віддаленістю від автошляхів та інтенсивністю руху автотранспортних засобів. Розглянуті місця дослідження умовно поділено на дві групи: слабко забруднені (середня часова інтенсивність руху автотранспорту менш ніж 1000 авто/год) та дуже сильно забруднені (інтенсивність руху на автомагістралях перевищує 4000 авто/год) [23]. До першої групи належать вулиці, що розміщені в межах "спальних" районів периферії Києва - вул. Ф. Максименка Оболонського р-ну (парк "Пуща Водиця", відстань від дороги 32 м, інтенсивність руху в середньому 860 авто/год, точка 1) та вул. Жмеринська Святошинського р-ну (парк "Совки", віддаленість від автошляху 3 м, інтенсивність руху 980 авто/год, точка 3) (рис. 1). До групи дуже сильно забруднених територій належать: проспект Перемоги (станція метро "Нивки", відстань від автомагістралей 7 м, інтенсивність руху 4387 авто/год, точка 2) Шевченківського р-ну та вулиця Генерала Жмаченка (парк "Перемога", поблизу станції метро "Дарниця", віддаленість від автошляху 35 м, навантаження 4167 авто/год, точка 4) Дніпровського р-ну.

Зразки $F$. europaea, які піддавалися надмірному впливу автомобільних вихлопів, зростали у культурфітоценозах Одеської площі на відстані 6 м від автомагістралі (точка 5), яка розміщена у Голосіївському р-ні, між проспектом Академіка Глушкова, вулицями Академіка Заболотного, Теремківською та Кільцевою дорогою 3 автотранспортним навантаженням у середньому 5690 авто/год. Загалом, за даними ЦГО ім. Серезневського, загальний рівень забруднення повітря за індексом забруднення атмосфери (IЗА) у Києві оцінювали як високий $[6,24]$. Зафіксовано перевищення середньодобових гранично допустимих концентрацій з діоксиду азоту у 3,0 рази, формальдегіду - в 2,0, діоксиду сірки - в 1,5 , фенолу - в 1,3 , оксиду азоту - в 1,2 раза. Найбільшу концентрацію забруднювальних речовин виявлено у місцях з інтенсивним рухом транспорту.

Для дослідження проби відбирали у червні, що зумовлено максимальними значеннями вмісту діоксиду азоту, формальдегіду та I3A $(11,9)$ саме у цей період, чому сприяли високі температури повітря та інтенсивність сонячної радіації $[6,24]$. Анатомо-морфологічну будову листків вивчали за загальноприйнятими методиками на тимчасових препаратах, виготовлених з морфологічно зрілих листків, зібраних з південної сторони середньої частини крони модельних кущів у 25-разовій повторюваності [1]. Поперечні зрізи готували із середньої третини довжини листків за допомогою леза від руки. Препарати досліджували за допомогою мікроскопа Nicon Eclipse E100 на збільшені $\times 10,40$. Анатомоморфологічні описи листкової пластинки, визначення індексу ксероморфності та продихового індексу виконували за методикою Васильєва [25]. Вимірювання структурних елементів листка здійснювали у програмі AxioVision Carl Zeiss 4.8.2. Отримані дані обробляли загальноприйнятими методами математичної статистики за допомогою програми MC Excel 97-2003 [14].

\section{Результати дослідження та їх обговорення / Research results and their discussion}

Листкова пластинка $F$. europaea біфаціальна, ланцетоподібної форми, 3 округло-клиноподібною основою та загостреною верхівкою, по краю зубчаста, за шкалою Б. Р. Васильєва товста. Її довжина в середньому змінюється від 7,2 см (Одеська площа, точка 5) до 7,7 см ("Пуща Водиця", точка 1), ширина - від 3,2 см (точка 1) до 3,6 см (точка 5). Верхня та нижня сторони розсіяноопушені одно- та багатоклітинними трихомами, пельтатними залозами, найбільша кількість яких зосереджена по центральній та бокових жилках з обох сторін листка. Адаксіальний і абаксіальний епідерміси складаються 3 одного шару паренхімних клітин та покриті шаром гребінчастої кутикули, значно товстішою 3 верхнього боку (рис. 2).
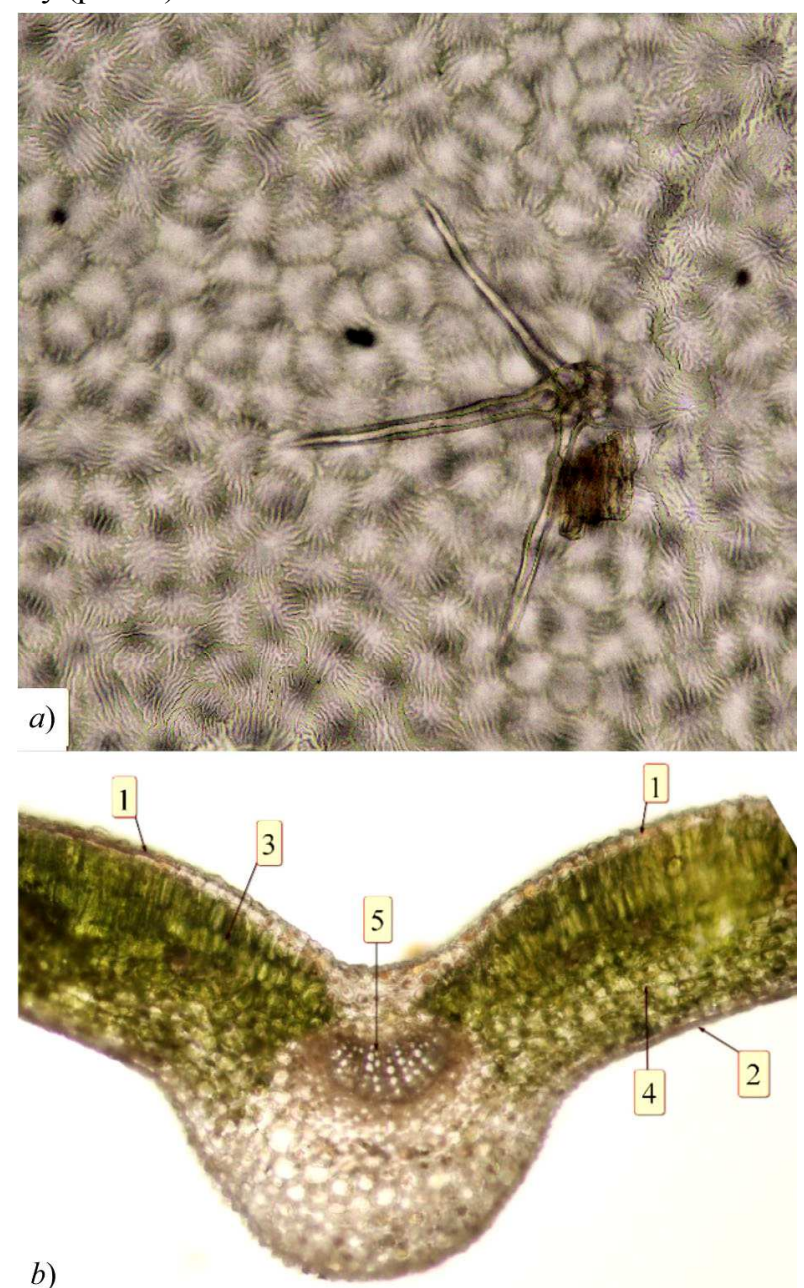

Рис. 2. Анатомічна будова листка $F$. europaea / Anatomical structure of $F$. europaea leaf: $a$ ) адаксіальний епідерміс / adaxial epidermis; $b$ ) поперечний розріз листка / cross-section of the leaf ( 1 - адаксіальний епідерміс / adaxial epidermis, 2 - абаксіальний епідерміс / abaxial epidermis, 3 - палісадний мезофіл / palisade mesophile, 4 - губчастий мезофіл / spongy mesophile, 5 - центральний провідний пучок / central vein) $(\times 40)$

Клітини верхнього епідермісу 5-6-кутної форми, 3 прямолінійними, або злегка гнутими стінками. Основні клітини абаксіальної епідерми витягнутої форми із сильно звивистими антиклінальними стінками (рис. 3). Товщина верхнього епідермісу в 1,5 раза перевищує розміри нижнього в усіх досліджених варіантах (табл. 1). Листок гіпостоматичний, продихи овальної форми, амоноцитного типу, розміщені безладно на одному рів- 
ні з епідермісом листка. Мезофіл дорзовентральний, утворений двома шарами палісадної паренхіми та 3-4 ша- рами губчастої з невеликою кількістю міжклітинників (див. рис. 2).

Табл. 1. Анатомічні показники поперечного зрізу листкової пластинки Forsythia europaea Degen \& Bald. в умовах Кисва / Anatomical parameters of the cross section of the leaf blade of Forsythia europaea Degen \& Bald. in Kyiv

\begin{tabular}{|c|c|c|c|c|c|c|}
\hline \multirow[t]{2}{*}{ Параметр } & $\begin{array}{l}\text { Моніторингова } \\
\text { ділянка }\end{array}$ & \begin{tabular}{|c|} 
Tочка 1 (парк \\
"Пуща Водиця")
\end{tabular} & $\begin{array}{l}\text { Точка } 2 \text { (станція } \\
\text { метро "Нивки") }\end{array}$ & $\begin{array}{c}\text { Точка } 3 \text { (парк } \\
\text { "Совки") }\end{array}$ & $\begin{array}{l}\text { Точка } 4 \text { (парк } \\
\text { "Перемога") }\end{array}$ & $\begin{array}{c}\text { Точка } 5 \\
\text { (Одеська } \\
\text { площа) }\end{array}$ \\
\hline & $\begin{array}{l}\text { Кількість авто/год } \\
\text { (середні показники) }\end{array}$ & 860 & 4387 & 980 & 4167 & 5690 \\
\hline \multirow{2}{*}{$\begin{array}{c}\text { Товщина листкової } \\
\text { пластинки, мкм }\end{array}$} & $M^{ \pm m}$ & $281,7^{ \pm 2,5}$ & $304,9^{ \pm 5,2}$ & $284,1^{ \pm 5,5}$ & $310,9^{ \pm 5,3}$ & $278,0^{ \pm 3,5}$ \\
\hline & $C V, \%$ & 4,4 & 8,5 & 9,5 & 8,6 & 6,3 \\
\hline \multirow{2}{*}{ Товщина кутикули, мкм } & $M^{ \pm m}$ & $6,1^{ \pm 0,2}$ & $8,1^{ \pm 0,3}$ & $6,6^{ \pm 0,3}$ & $7,8^{ \pm 0,4}$ & $8,4^{ \pm 0,3}$ \\
\hline & $C V, \%$ & 16,3 & 17,61 & 21,97 & 22,7 & 18,84 \\
\hline \multirow{2}{*}{$\begin{array}{c}\text { Товщина адаксіального } \\
\text { епідермісу, мкм }\end{array}$} & $M^{ \pm m}$ & $30,9^{ \pm 0,7}$ & $29,2^{ \pm 0,8}$ & $29,6^{ \pm 0,9}$ & $31,9^{ \pm 0,9}$ & $26,0^{ \pm 0,7}$ \\
\hline & $C V, \%$ & 11,7 & 14,2 & 14,4 & 12,9 & 15,2 \\
\hline \multirow{2}{*}{$\begin{array}{c}\text { Товщина абаксіального } \\
\text { епідермісу, мкм }\end{array}$} & $M^{ \pm m}$ & $20,2^{ \pm 0,7}$ & $20,4^{ \pm 0,6}$ & $20,1^{ \pm 0,5}$ & $20,0^{ \pm 0,8}$ & $18,3^{ \pm 0,5}$ \\
\hline & $C V, \%$ & 16,2 & 14,2 & 11,58 & 16,3 & 13,8 \\
\hline \multirow{2}{*}{ Товщина мезофілу, мкм } & $M^{ \pm m}$ & $224,0^{ \pm 3,0}$ & $255,0^{ \pm 5,1}$ & $227,3^{ \pm 6,2}$ & $257,4^{ \pm 5,3}$ & $226,7^{ \pm 2,8}$ \\
\hline & $C V, \%$ & 5,2 & 10,0 & 12,2 & 10,2 & 6,3 \\
\hline \multirow{2}{*}{$\begin{array}{c}\text { Товщина стовпчастого } \\
\text { мезофілу }\end{array}$} & $M^{ \pm m}$ & $91,4^{ \pm 2,3}$ & $107,3^{ \pm 3,2}$ & $96,0^{ \pm 3,2}$ & $94,1^{ \pm 4,2}$ & $90,8^{ \pm 2,9}$ \\
\hline & $C V, \%$ & 11,5 & 10,8 & 14,8 & 17,2 & 10,6 \\
\hline \multirow{2}{*}{$\begin{array}{c}\text { Товщина губчастого } \\
\text { мезофілу, мкм }\end{array}$} & $M^{ \pm m}$ & $136,5^{ \pm 2,6}$ & $152,7^{ \pm 4,}$ & $135,0^{ \pm 3,9}$ & $164,1^{ \pm 5,8}$ & $136,9^{ \pm 3,4}$ \\
\hline & $C V, \%$ & 8,6 & 9,9 & 13,2 & 13,9 & 8,3 \\
\hline
\end{tabular}

Примітка: $M^{ \pm m}$ - середне арифметичне і стандартне відхилення.

3'ясовано, що інгредієнти автомобільних викидів впливають на структурні елементи листкової пластинки $F$. europaea, передусім на покривні тканини, оскільки епідерміс рослин виконує бар'єрну та захисну функції, а зміни його структури відображають наслідки впливу умов навколишнього середовища на рослину загалом $[2,5,8,18,23]$. Так, в умовах сильного забруднення (точка 2, 4), порівняно із зразками з відносно чистої території (точки 1 та 3), рослини розвивали товщу кутикулу, що має важливе значення для їх захисту від впливу негативних чинників довкілля, зокрема і інгредієнтів автотранспортних викидів. Подібні дані отримали науковці під час дослідження як деревних, так і квітниково-декоративних рослин в умовах урбаносередовища $[5,11,18,20]$. Однак достовірної різниці у товщині верхньої та нижньої епідерм листків $F$. europaea за високого рівня забруднення та низького не виявлено. Натомість, у рослин 3 точки 5 (де найбільше автотранспортне навантаження) спостерігали найменші розміри адаксіального (26 ${ }^{ \pm 0,7}$ мкм) та абаксіального $\left(18,3^{ \pm 0,5}\right.$ мкм) епідермісів (див. табл. 1). За дослідженнями В. С. Ніко- лаєвського, зменшення товщини верхнього епідермісу може бути характерним для більш газостійких рослин, а збільшення його товщини свідчить про більшу чутливість виду до забруднення [21].

Встановлено, що викиди транспортних засобів насамперед вплинули на продиховий апарат рослин, через який здійснюється газообмін, транспірація та відбувається надходження токсичних речовин. Так, довжина та ширина замикаючих клітин продихів в умовах посиленого впливу на рослини аерозабруднювачів зменшується, а їх щільність на одиницю поверхні епідермісу $\left(1 \mathrm{Mм}^{2}\right)$ збільшується, тобто рослини набувають ознак ксероморфності, що узгоджується 3 дослідженнями інших науковців (табл. 2) [11, 13, 18, 19]. Менші показники продихів (довжина та ширина) зафіксовано у рослин, які зростали у більш забруднених місцях (точки $2,4,5$ ), а більші - у рослин, які вирощували на периферії Києва - парки "Пуща Водиця" та "Совки" (точки 1, 3). Ми відзначили різницю у відкритості продихів листків, яка збільшувалася в міру зменшення інтенсивності руху транспортних засобів.

Табл. 2. Вплив забруднення довкілля на показники продихового апарату листкової пластинки Forsythia europaea Degen \& Bald в умовах Кисва / Influence of environmental pollution on indicators of the stomata of a leaf of Forsythia europaea Degen \& Bald in Kyiv

\begin{tabular}{|c|c|c|c|c|c|c|}
\hline Показник & $\begin{array}{l}\text { Місце зби- } \\
\text { рання проб }\end{array}$ & $\begin{array}{c}\text { Точка } 1 \text { (парк } \\
\text { "Пуща Водиця") }\end{array}$ & $\begin{array}{l}\text { Точка } 2 \text { (станція } \\
\text { метро "Нивки") }\end{array}$ & $\begin{array}{c}\text { Точка } 3 \text { (парк } \\
\text { "Совки") }\end{array}$ & $\begin{array}{l}\text { Точка } 4 \text { (парк } \\
\text { "Перемога") }\end{array}$ & $\begin{array}{l}\text { Точка } 5 \text { (Одесь- } \\
\text { ка площа) }\end{array}$ \\
\hline \multirow{2}{*}{ Довжина продихів, мкм } & $M^{ \pm m}$ & $29,1^{ \pm 0,6}$ & $26,1^{ \pm 0,6}$ & $28,5^{ \pm 0,7}$ & $25,6^{ \pm 0,6}$ & $26,4^{ \pm 0,8}$ \\
\hline & $C V, \%$ & 10,3 & 12,1 & 13,0 & 10,8 & 14,5 \\
\hline \multirow{2}{*}{ Ширина продихів, мкм } & $M^{ \pm m}$ & $18,6^{ \pm 0,4}$ & $17,8^{ \pm 0,5}$ & $18,0^{ \pm 0,5}$ & $17,8^{ \pm 0,5}$ & $17,6^{ \pm 0,4}$ \\
\hline & $C V, \%$ & 9,8 & 13,5 & 13,1 & 13,5 & 12,1 \\
\hline \multirow{2}{*}{ Кількість продихів шт./1 мм² } & $M^{ \pm m}$ & $153^{ \pm 10}$ & $316,6^{ \pm 15}$ & $154^{ \pm 10}$ & $339^{ \pm 10,6}$ & $373^{ \pm 14,9}$ \\
\hline & $C V, \%$ & 21,8 & 13,4 & 16,4 & 12,8 & 11,3 \\
\hline \multirow{2}{*}{$\begin{array}{l}\text { Ширина продихової щілини, } \\
\text { мкм }\end{array}$} & $M^{ \pm m}$ & $8,3^{ \pm 0,4}$ & $7,1^{ \pm 0,4}$ & $7,8^{ \pm 0,4}$ & $7,6^{ \pm 0,3}$ & $6,7^{ \pm 0,4}$ \\
\hline & $C V, \%$ & 21,1 & 24,7 & 22,5 & 19,0 & 24,0 \\
\hline \multirow{2}{*}{$\begin{array}{l}\text { Кількість клітин нижнього } \\
\text { епідермісу на } 1 \text { мм², шт. }^{2}\end{array}$} & $M^{ \pm m}$ & $916^{ \pm 40,8}$ & $1233^{ \pm 50,1}$ & $955^{ \pm 17,5}$ & $1328^{ \pm 40,6}$ & $1255^{ \pm 42}$ \\
\hline & $C V, \%$ & 12,6 & 10,8 & 4,8 & 9,7 & 13,3 \\
\hline \multirow{2}{*}{ Продиховий індекс, \% } & $M^{ \pm m}$ & $14,6^{ \pm 0,9}$ & $19,2^{ \pm 0,9}$ & $13,6^{ \pm 0,9}$ & $18,8^{ \pm 0,75}$ & $23,6^{ \pm 0,8}$ \\
\hline & $C V, \%$ & 18,0 & 13,3 & 14,9 & 12,64 & 10,3 \\
\hline \multirow{2}{*}{ Індекс ксероморфності, \% } & $M^{ \pm m}$ & $10,7^{ \pm 0,5}$ & $16,4^{ \pm 0,5}$ & $11,1^{ \pm 0,3}$ & $17,1^{ \pm 0,7}$ & $16,5^{ \pm 0,9}$ \\
\hline & $C V, \%$ & 12,6 & 9,6 & 5,0 & 10,2 & 16,4 \\
\hline
\end{tabular}

Примітка: $M^{ \pm m}$ - середнє арифметичне і стандартне відхилення; $C V \%$ коефіцієнт варіації. 
Так, найменшу ширину продихової щілини зафіксовано у рослин з точки 5 (Одеська площа) - 6,7 мкм, а найбільшу - 8,3 мкм у точці 1 ("Пуща Водиця"). Із зростанням антропогенного навантаження зафіксовано збільшення кількості продихів на одиницю поверхні листка (у 2-2,4 раза) порівняно з особинами з відносно мало забруднених територій (див. табл. 2; рис. 3 ).
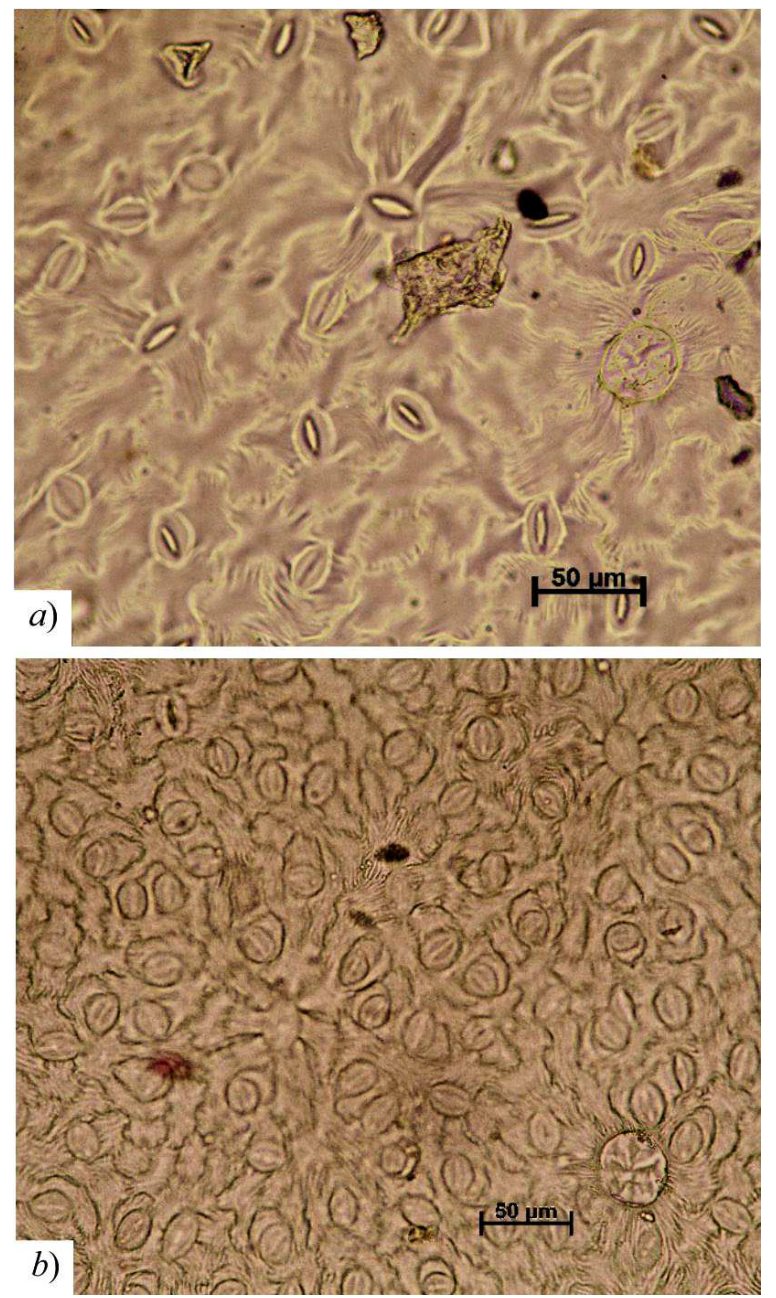

Рис. 3. Клітини абаксіального епідермісу / Abaxial epidermal cells: a) точка 1 / point 1 (парк "Пуща Водиця" / Pushcha Voditsa Park); b) точка 4 / point 4 (парк "Перемога" / Victory Park)

Варто зазначити, що у рослин за умов високої концентрації викидів (точка 2, 4, 5) поблизу центральної жилки з'являлися поодинокі продихи на адаксіальній поверхні листка. Зменшення відкритості продихів та збільшення їх кількості на одиницю поверхні сприяли скороченню надходження шкідливих речовин до рослинного організму, покращували регуляцію газообміну та транспірації, що, на наш погляд, є пристосувальною реакцією рослин на зростання у забруднених умовах. Наведені вище дані добре узгоджуються з результатами анатомічних досліджень рослин в урботехногенному середовищі $[11,13,19,26]$.

За умов збільшення ступеня навантаження автотранспортом зростає кількість клітин абаксіального епідермісу на одиницю площі і, відповідно, показники продихового індексу та індексу ксероморфності, що свідчить про ксероморфітизацію рослин під впливом полютантів. Найбільшу величину продихового індексу - 23,6 \% - зафіксовано в точці 5, що за визначенням Васильєва належить до дуже великого, тоді як у точках 2 та 4 він $є$ великим - 19,2 та 18,8 \%, а в точках 1 та 3 середнім 14,6 та 13 \% відповідно (див. табл. 2). Низькі показники індексу ксероморфності характерні для листків рослин 3 відносно чистої зони (парки "Пуща Водиця" та "Совки"), тоді як високі - для особин, що зростали в умовах посиленого впливу викидів автотранспорту (моніторингові точки 2, 4, 5).

У міру посилення забруднення вихлопними газами автотранспорту у рослин $F$. еuropaea відбувалося потовщення листків та мезофілу, окрім зразків 3 точки 5 (Одеська площа), де листок був найтоншим (див. табл. 1). Також зросли показники і губчастого мезофілу. Так, у екземплярів $F$. europaea 3 точок відбору матеріалу 2 та 4 товщина листка становила 304,9 та 310,9 мкм, мезофілу - 255 та 257,4 мкм, губчастої паренхіми - 152,7 та 164 мкм відповідно. Схожі результати отримали C. А. Сергейчик під час дослідження Partenocissus quinquefolia L. та O. А. Пономарьова під час вивчення анатомічної будови листків видів Tilia L. в умовах урбаносередовища $[20,26]$.

Ми здійснили кореляційний аналіз залежності показників елементів анатомічної структури листка від інтенсивності автопотоків. Виявлено тісний прямо пропорційний зв'язок між ступенем забруднення повітря автотранспортними вихлопами та товщиною кутикули $(r=0,98)$, щільністю продихів та кількістю клітин абаксіального епідермісу на одиницю поверхні листка $(r=$ $0,99$ та $r=0,95)$, величиною продихового індексу $(r=$ $0,97)$ та індексу ксероморфності $(r=0,95)$. Встановлено, що параметри продихового апарату обернено пропорційно корелюють 3 інтенсивністю навантаження транспортного руху (довжина продихів $r=-0,95$, ширина $r=-0,85$, відкритість продихів $r=-0,95)$, тобто із збільшенням забруднення продихові показники зменшуються. Найменший вплив автомобільне навантаження має: на товщину листкової пластинки, мезофілу, адаксіального епідермісу, що підтверджується низькими показниками кореляції ( $r=0,3, r=0,4$ та $r=-0,3$ відповідно) і середній на висоту клітин абаксіальної поверхні $(r=-0,6)$.

Обговорення результатів дослідження. Отже, порівнюючи отримані дані іншими вченими з результатами наших досліджень, можна констатувати, що забруднення передусім впливає на структуру листка, оскільки в ньому проходять основні процеси життєдіяльності рослин, а їх адаптація до умов середовища пов'язана із змінами в його будові. Виявлено, що рослини проявляють свої видоспецифічні пристосувальні реакції на дію полютантів. Для більшості з них характерна тенденція до ксероморфітизації. Такі результати отримали: Л. С. Лакшитова під час дослідження адаптації деревних рослин до забруднення повітря в м. Улан-Уде, Ю. М. Петрушкевич та Т. Ф. Чипиляк під час вивчення анатомо-морфологічних параметрів асиміляційного апарату Betula. pendula Roth та культиварів роду Hemerocallis L. на Криворіжжі, Н. В. Капелюш під час дослідження Platanus orientalis L. та інші дослідники [5, 11, $13,18,19]$. Зміни в анатомічній структурі листка, на погляд багатьох авторів, відбуваються внаслідок адаптивної реакції рослин на негативну дію забруднювачів, що свідчить про пластичність видів в умовах урбосередовища. 


\section{Висновок / Conclusions}

Встановлено особливості анатомо-морфологічної будови листків $F$. europaea в умовах Київського мегаполісу. Виявлено, що у варіантах, де рослини зазнавали більш інтенсивної дії інгредієнтів автотранспортних викидів, відбувалися зміни показників гістологічної структури листка у бік ксероморфності, а саме: потовщувалася кутикула (в 1,2-1,4 раза), зменшувалися розміри продихів, ступінь їх відкритості, збільшувалася їх щільність (у 2-2,4 раза) і клітин абаксіального епідермісу (в 1,3-1,4 раза), зростали показники продихового індексу та індексу ксероморфності (в 1,5-1,6 раза), з'являлися поодинокі продихи на адаксіальній поверхні листків. Такі зміни у структурі листка зумовлюють підвищення стійкості рослин в умовах забруднення середовища токсичними газами, що свідчить про достатній рівень адаптації виду в урбосередовищі. Вважаємо, що зміни параметрів гістологічної структури листка $F$. europaea можна використовувати як тест-показники для індикації аерогенного забруднення довкілля.

\section{References}

1. Barykina, R. P., Veselova, T. D., Devyatov, A. G., Dzhalilova, Kh. Kh., Ilina, G. M., \& Chubatova, N. V. (2004). Spravochnik po botanicheskoy mikrotekhnike. Osnovy i metody. Moscow: Izdatelstvo MGU, 312 p. [In Russian].

2. Beerling, D., \& Chaloner, W. (1993). Evolutionary responses of stomatal density to global $\mathrm{CO}_{2}$ change. Biological Journal of the Linnean Society, 48(4), 343-353. https://doi.org/10.1016/00244066(93)90005-9

3. Chayka, L. V., \& Tarkovs'ka, M. V. (2009). Avtotransport - odna z prychyn zabrudnennya atmosfernoho povitrya. Nauk. pr. Donets'koho natsional'noho tekhnichnoho universytetu. Seriya: Khimiya i khimichna tekhnolohiya, 152, 160-164. Retrieved from: http://ea.donntu.edu.ua/handle/123456789/2313

4. Chemerys, I. A., \& Klyuchka, S. I. (2021). Vmist fotosyntetychnykh pihmentiv u khvoyi sosny zvychaynoyi (Pinus sylvestris L.) v umovakh zapovidnykh obyektiv mista Cherkasy. Scientific Bulletin of UNFU, 31(4), 15-21. https://doi.org/10.36930/40310402

5. Chypylyak, T. F., \& Hryshko, V. M. (2008). Zminy anatomichnoyi budovy lystkiv vydiv ta sortiv liliynyku za diyi aerohennoho zabrudnennya Visnyk Kharkivs'koho natsional'noho ahrarnoho universytetu. Seriya biolohiya, 3(15), 58-65. Retrieved from: http://nbuv.gov.ua/UJRN/Vkhnau biol 2008 310

6. Ekolohichnyy pasport. (2020). Retrieved from: https://ecodep.kyivcity.gov.ua/files/2020/9/1/eco_pasport_2019.pdf,.

Retrieved from: https://www.autoconsulting.com.ua/article.php?sid $=48496$

7. Futorna, O. A., Ol'shans'kyy, I. H., \& Trofymenko, A. P. (2014). Anatomo morfolohichna budova lystkiv berezy povysloyi (Betula pendula Roth) v umovakh urbanoseredovyshcha. Visnyk Kyyivs'koho natsional'noho universytetu imeni Tarasa Shevchen$\mathrm{ka}$. Introduktsiya ta zberezhennya roslynnoho riznomanittya, 1(32), 55-60. Retrieved from: http://nbuv.gov.ua/UJRN/VKNU ItZ $2014 \quad 1 \quad 17$

8. Goncharenko, B. V. (2009). Perspektivi vikoristannya vidiv ta kultivariv rodu forzitsiya (Forsythia Vahl.) u zelenomu budivnitstvi v Pravoberezhnomu lisostepu Ukrayini. Introduktsiya roslin, 1, 68-72. [In Ukrainian].

9. Jun-Ho, S., \& Suk-Pyo, H. (2013). The systematic consideration of leaf epidermal microstructure in the tribe Forsythieae and its related genera (Oleaceae). Korean Journal of Plant Taxonomy, 43(2), 118-127. https://doi.org/10.11110/kjpt.2013.43.2.118

10. Kapelyush, N. V., \& Bessonova, V. P. (2005). Zmina anatomichnykh pokaznykiv lystkiv Platanus orientalis L. pid diyeyu promyslovykh emisiy (tekhnohennoho navantazhennya). Introduktsiya roslyn, 1, 81-87. [In Ukrainian].
11. Kryvoruchko, A. P., \& Bessonova, V. P. (2017). Pokaznyky anatomichnoyi struktury lystkiv duba chervonoho (Quercus rubra L.) $\mathrm{v}$ urbotekhnohennykh umovakh. Visnyk L'vivs'koho universytetu. Seriya biolohichna, 76, 29-37. http://nbuv.gov.ua/UJRN/VLNU_biol_2017_76_6

12. Lakyn, F. F. (1990). Byometryya. Moscow: Vysshaya shkola, 352 p. [In Russian].

13. Luo, H., Tang, Q., Shang, Y., Liang, Sh., Yang, M., Robinson, N., \& Liu, J. P. (2020). Chinese Medicine Be Used for Prevention of Corona Virus Disease 2019 (COVID-19)? A Review of Historical Classics, Research Evidence and Current Prevention Programs. Chin $J$ Integr Med., 26(4), 243-250. https://doi.org/10.1007/s11655-020-3192-6

14. Lykshitova, L. S., \& Lovtsova, N. M. (2014). Morfologicheskaya adaptatsiya derevyev i kustarnikov k zagryazneniyu atmosfernogo vozdukha g. Ulan-Ude. Vestnik Buryatskogo gosudarstvennogo universita 4(1), 51-54. [In Russian].

15. Matusyak, M. V., \& Varhatyuk, O. V. (2020). Vyznachennya dekoratyvnosti ta uspishnosti introduktsiyi vydiv rodu Forsythia Vahl. v umovakh biostatsionaru VNAU. Visnyk Umans'koho Natsional'noho universytetu sadivnytstva, 1, 124-128. https://doi.org/10.31395/2310-0478-2020-1-124-128

16. Mazura, M. Yu., Leshchenyuk, O. M., Teslenko, I. K., \& Yurchuk, M. I. (2020). Analiz chutlyvosti pylku roslyn Canna L. v umovakh aerotekhnohennoho presynhu. Ekolohichni nauky, 3(30), 182-187. https://doi.org/10.32846/2306-9716/2020.eco.3$\underline{30.30}$

17. Nikolaevskiy, V. S. (1979). Biologicheskie osnovyi gazoustoychivosti rasteniy: monografiya. Novosibirsk: Nauka, 280 p. [In Russian].

18. Petrushkevych, Yu. M. (2021). Zhyttyezdatnist Betula pendula Roth v umovakh Kryvorizhzhya. Abstract of Candidate Dissertation for Biology Sciences (03.00.16.). Dnipro, 26 p. https://www.dnu.dp.ua/docs/nde/dissertations/D08.051.04/autoreferat 600818 f9081c1.pdf.

19. Ponomar'ova, O. A. (2013). Zminy anatomichnoyi budovy lystkiv derev rodu Tilia L. yak pokaznyk adaptatsiyi do riznykh umov zrostannya. Pytannya bioindykatsiyi ta ekolohiyi, 18(2), 105-120. Retrieved from: http://nbuv.gov.ua/jpdf/pbte_2013_18_2_12.pdf

20. Pourkhabbaz, A., Rastin, N., Olbrich, A., Langenfeld-Heyser, \& Polle, A. (2010). Influence of Environmental Pollution on Leaf Properties of Urban Plane Trees, Platanus orientalis L. Bulletin of Environmental Contamination and Toxicology, 85, 251-255. https://doi.org/10.1007/s00128-010-0047-4

21. Pryseds'kyy, Yu. H., \& Lykholat, Yu. V. (2017). Adaptatsiya roslyn do antropohennykh chynnykiv (pidruchnyk dlya studentiv spetsial'nostey biolohiya, ekolohiya ta serednya osvita vyshchykh navchal'nykh zakladiv). Vinnytsya: TOV "Nilan-LTD", 98 p. [In Ukrainian].

22. Serdyuk, S. M. (2016). Aktual'ni problemy ekolohichnoyi transformatsiyi mis'koho seredovyshcha $\mathrm{v}$ umovakh vysokoho avtotransportnoho navantazhennya (na prykladi m. Dnipropetrovs'k). Elektromahnitna sumisnist' ta bezpeka na zaliznychnomu transporti, 11, 101-108. Retrieved from: http://nbuv.gov.ua/UJRN/esbzt_2016_11 16

23. Sergeychik, S. A. (1994). Ustoychivost drevesnykh rasteniy v tekhnogennoy srede. Minsk: Navuka í têkhníka, 279 p. [In Russian].

24. Sun, L., Rai, A., Rai, M., Nakamura, M., Kawano, N., Yoshimatsu, K., Suzuki, H., Kawahara, N., Saito, K., \& Yamazaki, M. (2018). Comparative transcriptome analyses of three medicinal Forsythia species and prediction of candidate genes involved in secondary metabolisms. Journal of Natural Medicines, 72(4), 867-881. https://doi.org/10.1007/s11418-018-1218-6

25. Vasilyev, B. R. (1988). Stroyeniye lista drevesnykh rasteniy razlichnykh klimaticheskikh zon. Leningrad: Izd-vo Leningradskogo universiteta, 208 p. [In Russian].

26. Zabrudnennya. (2020). Shchorichnyk stanu zabrudnennya atmosfernoho povitrya na terytoriyi Ukrayiny za danymy sposterezhen' hidrometeorlohichnykh orhanizatsiy za 2019 TS.HO im. B. Sreznevs'koho. Kyiv, 271 p. 


\section{CHANGES IN THE ANATOMICAL PARAMETERS OF THE LEAVES OF FORSYTHIA EUROPAEA DEGEN \& BALD. CAUSED BY MOTOR VEHICLE EMISSIONS}

At a time of high motorization, it is important to study the impact of ingredients of motor vehicle emissions on green spaces in megacities, which maintain the ecological balance in the urban ecosystem and serve as indicators of environmental pollution. Forsythia europaea Degen \& Bald. is widely used in the phytodesign of Kyiv in various places that are subject to constant anthropogenic pressure. Therefore, it is expedient to anatomically and morphologically study the structure of $F$. europaea leaves to determine the stability of the species in the conditions of the Kyiv metropolis and to monitor environmental pollution. The study was based on F. europaea plants selected from 5 monitoring sites in Kyiv, which differed in traffic intensity and distance from highways: lightly polluted (average time intensity of traffic less than 1000 cars/hour) and very heavily polluted (traffic intensity exceeds 4000 cars/hour). The overall level of air pollution according to the Air Pollution Index (API) in Kyiv is assessed to be high. Samples were taken in June at maximum values of nitrogen dioxide, formaldehyde and API (11.9). The study was conducted according to the method by Barykina (2004), Vasiliev (1988). The peculiarities of anatomical and morphological structure of $F$. europaea leaves under different growth conditions have been established. As a result, we have found that the leaves are hypostomatic, covered with cuticles on both sides. The adaxial and abaxial epidermis are formed by a single layer of cells. The mesophile is multilayered, dorsoventral. Our study has detected that there were changes in the histological structure of the leaves in the direction of xeromorphism in plants with increasing intensity of automobile load. The cuticle is thickened, the size of the stomata and the degree of their openness decreased. The density of stomata and cells of the abaxial epidermis increased, the indices of the stomatal index and the xeromorphism index increased, and single stomata appeared on the adaxial surface of the leaves. Such changes in the anatomical structure of the leaf blade of F. europaea can be considered as an adaptive response of plants to growth in anthropogenically transformed environment, which indicates the plasticity of the species and a sufficient level of adaptation to pollution. We believe that changes in the parameters of the histological structure of the leaf $F$. europaea can be used as indicators of environmental pollution.

Keywords: pollution; Forsythia Vahl.; leaf anatomy; plasticity; xeromorphitization. 